17. Ruben FL, Johnston F, Streiff EJ. Influenza in a partially immunized aged population: effectiveness of killed Hong Kong vaccine against infection with the England strain. JAMA 1974;230:863-866.

18. Barker WH, Borisute $\mathrm{H}$, Cox C. A study of the impact of influenza on the functional status of frail older people. Arch Intern Med 1998;158: $645-650$.

19. Mathur U, Bentley DW, Hall CB. Concurrent respiratory syncytial virus and influenza $A$ infections in the institutionalized elderly and chronically ill. Ann Intern Med 1980;93:49-52.

20. Hall WN, Goodman RA, Noble GR, Kendal AP, Steece RS. An outbreak of influenza B in an elderly population. I Infect Dis 1981;144:297-302.

21. Hart RJ. An outbreak of respiratory syncytial virus infection in an old people's home. I Infect 1984;8:259-261.

22. Falsey AR, Treanor JJ, Betts RF, Walsh EE. Viral respiratory infections in the institutionalized elderly: clinical and epidemiologic findings. J $\mathrm{Am}$ Geriatr Soc 1992;40:115-119.

23. Nicholson KG, Baker DJ, Farquhar A, Hurd D, Kent J, Smith SH. Acute upper respiratory tract viral illness and influenza immunization in homes for the elderly. Epidemiol Infect 1990;105:609-618.

24. Wald TG, Miller BA, Shult P, Drinka P, Langer L, Gravenstein S. Can respiratory syncytial virus and influenza $A$ be distinguished clinically in institutionalized older persons? J Am Geriatr Soc 1995;43:170-174

25. Garner JS, Hospital Infection Control Practices Advisory Committee. Guideline for isolation precautions in hospitals. Infect Control Hosp Epidemiol 1996;17:53-80.

26. Leclair JM, Freeman J, Sullivan BF, Crowley CM, Goldmann DA Prevention of nosocomial respiratory syncytial virus infections through compliance with glove and gown isolation precautions. $N$ Engl J Med 1987;317:329-334.

27. Moser MR, Bender TR, Margolis HS, Noble GR, Kendal AP, Ritter DG. An outbreak of influenza aboard a commercial airliner. Am J Epidemiol 1979;110:1-6.

28. Dick EC, Jennings LC, Mink KA, Wartgow CD, Inhorn SL Aerosol transmission of rhinovirus colds. I Infect Dis 1987;156:442-448.

\title{
Povidone-Iodine Versus Iodine Tincture for Venipuncture-Site Disinfection
}

\section{Gina Pugliese, RN, MS Martin S. Favero, PhD}

Little and coinvestigators from Washington University School of Medicine, St Louis, Missouri, conducted a study to determine if the method of disinfection at the venipuncture site could reduce contamination rates of blood cultures. Antecubital venipuncture sites were randomly disinfected with povidone-iodine or iodine tincture, and blood cultures (two bottles,
$10 \mathrm{~mL}$ of blood) were drawn by professional phlebotomists. Scoring of contaminant species was restricted to skin flora.

Of the 3,851 blood cultures collected during the study, 120 (3\%) were contaminated with skin flora. The contamination rate for blood cultures collected after povidone-iodine was $4 \%$ $(74 / 1,947)$, compared with a rate of $2 \%$ $(46 / 1,904 ; P=.01)$ after iodine tincture. The difference in mean total hospital costs for patients with contaminated blood cultures and those with sterile blood cultures was $\$ 4,100$ (95\% confidence interval, $\$ 740-\$ 7,400 ; P=.02)$.

The authors concluded that iodine tincture is superior to povidoneiodine for venipuncture-site antisepsis before blood-culture sampling.

FROM: Little JR, Murray PR, Traynor PS, Spitznagel E. A randomized trial of povidone-iodine compared with iodine tincture for venipuncture site disinfection: effects on rates of blood culture contamination. $A m J$ Med 1999;107:119-125. 